\title{
Effects of Progesterone on in Vitro Developmental Competence of Bovine Embryos
}

\author{
Orhan Örnek ${ }^{1, a}$, Yusuf Ziya Güzey ${ }^{1, b, *}$ \\ ${ }^{I}$ Department of Animal Science, Faculty of Agriculture, Hatay Mustafa Kemal University, 31060, Hatay, Turkey \\ *Corresponding author
}

\begin{tabular}{|c|c|}
\hline A R T I C L E I N F O & A B S T R A C T \\
\hline $\begin{array}{l}\text { Keywords: } \\
\text { Bovine } \\
\text { Embryo culture } \\
\text { Progesterone } \\
\text { In vitro fertilization } \\
\text { Embryo development }\end{array}$ & $\begin{array}{l}\text { Progesterone plays a key role in the establishment and maintenance of pregnancy in mammalian. } \\
\text { Increasing levels of circulating progesterone in the post-conception period are associated with } \\
\text { conceptus elongation and high pregnancy rates in cattle. Contradictory results are available on the } \\
\text { direct role of progesterone in early embryo development. The objective of this study was to evaluate } \\
\text { direct effects of progesterone on in vitro development of cattle embryos. Immature oocytes collected } \\
\text { from slaughtered animals and cultured in the presence of different concentrations of progesterone } \\
(25,50,100 \mathrm{ng} / \mathrm{mL}) \text { following in vitro fertilization. Cleavage rates in } 25 \text { and } 50 \mathrm{ng} / \mathrm{mL} \\
\text { concentrations of progesterone were significantly higher than those in controls and } 100 \mathrm{ng} / \mathrm{mL} \text {. Rate } \\
\text { of embryos that reached to the morula stage was similar in all groups. Supplementation of } 25 \mathrm{and} 50 \\
\text { ng/mL progesterone to the culture media significantly increased blastocyst yield while } 100 \mathrm{ng} / \mathrm{mL} \\
\text { progesterone resulted in a decrease. As a conclusion, we can suggest that progesterone } \\
\text { supplementation in in vitro culture may support embryo development at low levels. }\end{array}$ \\
\hline
\end{tabular}

\section{Introduction}

Most of the embryonic losses in cows occur during the early embryonic development period (Carter et al., 2008). The embryonic environment is crucial in shaping the embryonic development rate in the post-fertilization period (Carter et al., 2008). The elevated concentration of circulating progesterone immediately after pregnancy is closely related to the establishment of pregnancy in cattle (Carter et al., 2008; Clemente et al., 2009). In vivo and in vitro studies on both the direct (Ferguson et al., 2005; Merlo et al., 2006; Larson et al., 2011; Ferguson et al., 2012) and indirect (Bazer et al., 2010, Lonergan et al., 2016) effects of progesterone on embryo is available.

Existing contradictory results may be due to the differences in culture systems or the period in which the embryo is exposed to progesterone (Clemente et al., 2009). As a matter of fact, progesterone concentration in cows increases from day 3 following estrus. Progesterone treatments prior to the fertilization lead to a decrease in cleavage rates (Ferguson et al., 2012). Data on negative effects of progesterone during in vitro maturation (Fukui et al., 1982) and in vitro fertilization (Fukushima and Fukui, 1985) stages are also available. However, elevated concentrations of progesterone are accepted as an indicator of infertility (Ferguson et al., 2012). Timing of exposure to progesterone is crucial for embryo development in mammals, in this regard. Therefore, the main objective of this study was to determine whether supplementation of progesterone during in vitro culture directly alerts embryo development or not.

\section{Materials and Methods}

\section{Ethical Statement}

No approval from the research ethics committee was requested since embryos are not included in the list of organisms that require a specific authorization according to EC Directive 86/609/EEC for animal experiments.

\section{Chemicals}

Cell culture media for in vitro production (IVP) of bovine embryos were purchased from Caisson Labs (East Smithfield, UT, USA) unless otherwise indicated. Sperm preparation (SP)-Tyrode's Lactate (TL), IVF-TL, HepesTL and potassium simplex optimized medium including 
amino acids (KSOM+AA) used to prepare SP-Tyrode's albumin lactate pyruvate (TALP), Hepes-TALP, IVFTALP and KSOM-bovine embryo (KSOM-BE) as previously described by Parrish (2014) and Loureiro et al. (2007).

Oocyte selection media (OSM) was medium 199 (M199) with Hanks' salts, L-glutamine, hepes and indicator of phenol red (Thermo Fisher Scientific) supplemented with $100 \mu \mathrm{g} / \mathrm{mL}$ penicillin, $100 \mathrm{U} / \mathrm{mL}$ streptomycin and 5\% v/v fetal bovine serum (FBS). Oocyte maturation medium (OMM) was M199 with Glutamax ${ }^{\mathrm{TM}}$ and phenol red without hepes (Thermo Fisher Scientific) supplemented with $2.2 \mathrm{mg} / \mathrm{mL}$ sodium bicarbonate, $10 \%$ $\mathrm{v} / \mathrm{v}$ FBS, $5 \mu \mathrm{g} / \mathrm{mL}$ gentamycin, $0.22 \mathrm{mg} / \mathrm{mL}$ sodium pyruvate and gonadotropins (estradiol, LH and FSH).

\section{Collection of Ovaries and COCs}

Ovaries from slaughtered cows were derived from a local abattoir in Hatay/Turkey $\left(35^{\circ} 52^{\prime}-37^{\circ} 40^{\prime} \mathrm{N}\right.$ and $\left.35^{\circ} 40^{\prime}-36^{\circ} 35^{\prime} \mathrm{E}\right)$ and transported to the laboratory in prewarmed $\left(35^{\circ} \mathrm{C}\right)$ phosphate buffered saline (PBS; 0.01 M phosphate buffer, $0.0027 \mathrm{M}$ potassium chloride and 0.137 $\mathrm{M}$ sodium chloride, $\mathrm{pH} 7.4$, at $25^{\circ} \mathrm{C}$ ) supplemented with $100 \mu \mathrm{g} / \mathrm{mL}$ streptomycin, $100 \mathrm{U} / \mathrm{mL}$ penicillin in $2 \mathrm{~h}$ following the collection of the first ovary. IVP performed as previously described (Soto et al., 2003) but in brief follicular fluid including cumulus-oocyte complexes (COCs) from follicles (2-8 $\mathrm{mm} \varnothing)$ were aspirated using a $21 \mathrm{~g}$ needle mounted to a sterile syringe. After allowing COCs to gravitate in sterile centrifuge tubes, supernatant follicular fluid removed. Debris including COCs then transferred into petri dishes containing OSM and classified under a stereomicroscope $(\times 10-40)$ according to the method of Boni et al. (2002). COCs with at least 3 layers of compact cumulus cells surrounding a homogenous evenly granulated cytoplasm were classified as immature, transferred into OMM. In vitro maturation took place in a humidified atmosphere of $5 \% \mathrm{CO}_{2}$ in the air and lasted for 18-22h. COCs then transferred into IVF-TALP and fertilization procedure was completed by the addition of diluted sperm $\left(1 \times 10^{6}\right.$ spermatozoa/mL), heparin and PHE cocktail $(20 \mu \mathrm{M}$ penicillamine, $10 \mu \mathrm{M}$ hypotaurine, $1 \mu \mathrm{M}$ epinephrine in final concentration). Gametes were cultured together for $8-12 \mathrm{~h}$ under conditions of humidified atmosphere and $5 \% \mathrm{CO}_{2}$ in the air. Putative zygotes were denuded of cumulus cells and randomly transferred into KSOM-BE supplemented with $3 \mathrm{mg} / \mathrm{mL}$ fatty acid free bovine serum albumin (FAF-BSA) and $2.5 \mu \mathrm{g} / \mathrm{mL}$ gentamicin. In vitro culture of embryos performed under a humidified atmosphere of $5 \% \mathrm{CO}_{2}$ and $5 \% \mathrm{O}_{2}$ with the balance of $\mathrm{N}_{2}$.

The zygotes divided into 4 groups of which $\mathrm{C}$ was the control, and the experimental groups were designated as 25P, 50P and 100P, to test the direct effect of 25, 50 and $100 \mathrm{ng} / \mathrm{mL}$ of progesterone on embryo development.

\section{Statistical Analyses}

Frequency charts used to interpret data of the present experiment. Rate of embryos in any developmental stage arc-sine and square root transformed since they did not exhibit normal distribution and analysed with ANOVA. Differences between treatments executed using Duncan multiple comparison test.

\section{Results and Discussion}

Fertilization success in in vitro embryo production is typically high ( $90 \%)$, but a significant proportion of embryos fail to develop to blastocysts (Carter et al., 2008; Lonergan et al., 2016). The environment of in vitro culture to which the embryo is exposed is crucial in determining the rate of embryos to develop further stages (QuezadaCasasola et al., 2018; Sen and Kuran, 2018). Most studies have agreed that an elevated concentration of circulating progesterone in vivo is associated with an increase in pregnancy rate in cattle (Stronge et al., 2005; McNeill et al., 2006). In addition to the indirect effects of progesterone, many in vitro studies were conducted to evaluate the direct effects of progesterone on embryo development. However, these studies exhibited conflicting results with positive (Merlo et al., 2006; Ferguson et al., 2012) and negative (Clemente et al., 2009; Larson et al., 2011) effects. The reasons for these varying results have been explained previously. The first cleavage rates of COCs $(n=816)$, derived from 2-8 mm follicles of Holstein cows, are shown in Table 1.

Table 1. Cleavage rates of embryos

\begin{tabular}{l|ccccc}
\hline \multicolumn{1}{c|}{ Developmental stages } & Control $(\mathrm{n}=193)$ & $25 \mathrm{P}(\mathrm{n}=210)$ & $50 \mathrm{P}(\mathrm{n}=212)$ & $100 \mathrm{P}(\mathrm{n}=201)$ & $\mathrm{P}$ \\
\hline 2-cell & $78.8 \pm 1.23^{\mathrm{a}, \mathrm{b}}$ & $88.6 \pm 0.35^{\mathrm{b}}$ & $82.1 \pm 0.45^{\mathrm{b}}$ & $53.7 \pm 2.68^{\mathrm{a}}$ & \multirow{2}{*}{0.027} \\
Egg & $21.2 \pm 1.23^{\mathrm{a}, \mathrm{b}}$ & $11.4 \pm 0.35^{\mathrm{a}}$ & $17.9 \pm 0.45^{\mathrm{a}}$ & $46.3 \pm 2.68^{\mathrm{b}}$ & \\
\hline
\end{tabular}

Values are $\% \pm$ SEM, different letters of superscript in a row represent different groups according to Duncan

Elevated concentrations of progesterone at an appropriate level have been associated with improved embryonic development (Carter et al., 2008). Moreover, excessive concentrations of progesterone may disturb luteolytic signals and production of interferon-tau, and therefore luteolysis (Ferguson et al., 2012). Progesterone, in this experiment, has administered at the end of phase one, which corresponds the time zygote in the oviduct and phase 2 which corresponds the embryo moves into the uterus. Addition of progesterone to the culture media of in vitro produced embryos significantly enhanced cleavage rates at thereabout physiological concentrations ( 25 and 50 $\mathrm{ng} / \mathrm{mL})$ but resulted in a decrease at a supra-optimal (100 $\mathrm{ng} / \mathrm{mL})$ concentration $(\mathrm{P}<0.05)$. Glycolysis starts with the activation of the embryonic genome, subsequent to the 816 cell block. Glucose uptake is essential for embryonic development but excessive glycolysis induces a decrease in embryo viability (Yetkin-Arik et al., 2019; Cagnone and Sirard, 2016). This decrease in embryo viability is associated with an increase in metabolic stress. Pyruvate is the main source of energy for embryos at early stages. Elevated concentrations of progesterone result in an increase in metabolic stress and thus prevent embryonic development (Larson et al., 2011). 
The fact remains that the differences observed for morula stage embryos were not statistically significant, a slight increase in the proportion of embryos was notable for $25 \mathrm{P}$ and $50 \mathrm{P}$ groups (Table 2). Progesterone exhibit actions through binding nuclear receptors. It's been reported that progesterone receptors detected at any stage of embryo development except for morula (Clemente et al., 2009; Salehnia and Zavareh, 2013). In agreement with previous studies, supplementation of progesterone during in vitro culture did not impact morula yield in the present study (Table 2).

Table 2. Embryo yields during embryo development

\begin{tabular}{l|ccccc}
\hline & $\mathrm{C}(\mathrm{n}=152)$ & $25 \mathrm{P}(\mathrm{n}=186)$ & $50 \mathrm{P}(\mathrm{n}=173)$ & $100 \mathrm{P}(\mathrm{n}=108)$ & $\mathrm{P}$ \\
\hline Morula $(\%)$ & $45.4 \pm 0.03$ & $59.7 \pm 0.01$ & $55.2 \pm 0.01$ & $43.5 \pm 1.45$ & $\mathrm{NS}$ \\
Blastocyst $(\%)$ & $30.3 \pm 0.00^{\mathrm{a}, \mathrm{b}}$ & $37.1 \pm 0.01^{\mathrm{b}}$ & $35.6 \pm 0.01^{\mathrm{b}}$ & $27.8 \pm 0.36^{\mathrm{a}}$ & 0.009 \\
\hline
\end{tabular}

Values are $\% \pm$ SEM, different letters of superscript in a row represent different groups according to Duncan; NS: non-significant

Supplementation of the culture media with progesterone in varying concentrations significantly enhanced blastocyst yield at physiological levels (25 and $50 \mathrm{ng} / \mathrm{mL}$ ), but resulted in a decrease at a supra-optimal concentration $(100 \mathrm{ng} / \mathrm{ml})$, in the present study (Table 2). These findings suggest that progesterone may act directly as a survival factor on embryo development in vitro.

As conclusion, supplementation of culture media with progesterone at physiological levels immediately after fertilization may improve embryo development. Further research has to be conducted in order to determine the direct effects of progesterone on Blastomere count, quality grade and diameter of embryos.

\section{Acknowledgement}

The financial support of the Scientific Research Projects Coordination Unit of Mustafa Kemal University (Grant no. 16581) is gratefully acknowledged. This article has been generated from the Mater's thesis.

\section{References}

Aparicio IM, Garcia-Herreros M, O'Shea LC, Hensey C, Lonergan P, Fair T. 2011. Expression, regulation, and function of progesterone receptors in bovine cumulus oocyte complexes during in vitro maturation. Biol Reprod. 84: 910 921. doi: https://doi.org/10.1095/biolreprod.110.087411

Bazer FW, Wu G, Spencer TE, Johnson GA, Burghardt RC, Bayless K. 2010. ovel pathways for implantation and establishment and maintenance of pregnancy in mammals. ol. Hum. Reprod. 16, 135-152. doi: https://doi.org /10.1093/molehr/gap095

Boni R, Cuomo A, Tosti E. 2002. Developmental potential in bovine oocytes is related to cumulus-oocyte complex grade, calcium current activity, and calcium stores. Biol Reprod. 66: 836-842. doi: https://doi.org/10.1095/biolreprod66.3.836

Cagnone G, Sirard MA. 2016. The embryonic stress response to in vitro culture: insight from genomic analysis. Reproduction. 152(6): R247-R261. doi: https://doi.org/10.1530/REP-160391

Carter F, Forde N, Duffy P, Wade M, Fair T, Crowe MA, Evans AC, Kenny DA, Roche JF, Lonergan P. 2008. Effect of increasing progesterone concentration from day 3 of pregnancy on subsequent embryo survival and development in beef heifers. Reprod Fertil Dev. 20: 368-375. doi: https://doi.org/10.1071/RD07204

Clemente M, de La Fuente J, Fair T, Al Naib A, Gutierrez-Adan A, Roche JF, Rizos D, Lonergan P. 2009. Progesterone and conceptus elongation in cattle: A direct effect on the embryo or an indirect effect via the endometrium? Reproduction. 138: 507-517. doi: https://doi.org/10.1530/rep-09-0152
Ferguson CE, Davidson TR, Mello MRB, Lima AS, Kesler DJ, Wheeler MB, Godke RA. 2005. Evidence of a direct effect of p4 on ivf-derived bovine 8-cell embryos. Reproduction, Fertility and Development. 17: 219-219. doi: https://doi.org/10.1071/RDv17n2Ab136

Ferguson CE, Kesler DJ, Godke RA. 2012. Progesterone enhances in vitro development of bovine embryos. Theriogenology. 77: 108-114. doi: https://doi.org /10.1016/j.theriogenology.2011.07.022

Fukui Y, Fukushima M, Terawaki Y, Ono H. 1982. Effect of gonadotropins, steroids and culture media on bovine oocyte maturation in vitro. Theriogenology. 18: 161-175. doi: https://doi.org/10.1016/0093-691X(82)90100-5

Fukushima M, Fukui Y. 1985. Effects of gonadotropins and steroids on the subsequent fertilizability of extrafollicular bovine oocytes cultured in vitro. Animal Reproduction Science. 9: 323-332. doi: https://doi.org/10.1016/03784320(85)90061-2

Larson JE, Krisher RL, Lamb GC. 2011. Effects of supplemental progesterone on the development, metabolism and blastocyst cell number of bovine embryos produced in vitro. Reprod Fertil Dev. 23: 311-318. doi: https://doi.org/10.1071/rd10106

Lonergan P, Forde N, Spencer T. 2016. Role of progesterone in embryo development in cattle. Reprod Fertil Dev. 28: 66-74. doi: https://doi.org/10.1071/rd15326

Loureiro B, Brad AM, Hansen PJ. 2007. Heat shock and tumor necrosis factor-alpha induce apoptosis in bovine preimplantation embryos through a caspase-9-dependent mechanism. Reproduction. 133: 1129-1137. doi: https://doi.org/10.1530/rep-06-0307

McNeill RE, Diskin MG, Sreenan JM, Morris DG. 2006. Associations between milk progesterone concentration on different days and with embryo survival during the early luteal phase in dairy cows. Theriogenology. 65: 1435-1441. doi: https://doi.org/https://doi.org/10.1016/j.theriogenology. 2005.08.015

Merlo B, Iacono E, Mari G. 2006. Effect of progesterone and epidermal growth factor on in vitro-produced eight-cell bovine embryos in a serum-free culture medium. Reproduction, Fertility and Development. 19: 211-211. doi: https://doi.org/10.1071/RDv19n1Ab189

Parrish JJ. 2014. Bovine in vitro fertilization: In vitro oocyte maturation and sperm capacitation with heparin. Theriogenology. 81: 67-73. doi: https://doi.org/10.1016 j.theriogenology.2013.08.005

Quezada-Casasola A, Martínez-Armendáriz KE, Itzá-Ortiz MF, Escárcega-Ávila AM, Pérez-Eguía E, Filipiak Y, Larocca C, Carrera-Chávez JM. 2018. Effect of presence of corpora lutea on cumulus expansion of in vitro matured bovine oocytes selected by trypan blue and brilliant cresyl blue tests. Journal of Applied Animal Research. 46: 967-972. doi: https://doi.org/10.1080/09712119.2018.1440566

Salehnia M, Zavareh S. 2013. The effects of progesterone on oocyte maturation and embryo development. Int J Fertil Steril. 7: 74-81. doi: 
Sen U. Kuran M. 2018. Low incubation temperature successfully supports the in vitro bovine oocyte maturation and subsequent development of embryos. Asian-Australas J Anim Sci. 31: 827-834. doi://https:doi.org/10.5713/ajas.17.0569

Soto P, Natzke RP, Hansen PJ. 2003. Actions of tumor necrosis factor-alpha on oocyte maturation and embryonic development in cattle. Am J Reprod Immunol. 50: 380-388. doi: https://doi.org/10.1034/j.1600-0897.2003.00101.x
Stronge AJH, Sreenan JM, Diskin MG, Mee JF, Kenny DA, Morris DG. 2005. Post-insemination milk progesterone concentration and embryo survival in dairy cows. Theriogenology. 64: 1212-1224. doi: https://doi.org /https://doi.org/10.1016/j.theriogenology.2005.02.007

Yetkin-Arik B., Vogels IMC, Nowak-Sliwinska P., Weiss A, Riekelt HH, Cornelis JF Van Noorden, Klaassen I, Reiner OS. 2019. The role of glycolysis and mitochondrial respiration in the formation and functioning of endothelial tip cells during angiogenesis. Sci Rep, 12608. doi:10.1038 /s41598-019-48676-2 